\title{
PENGELOLAAN ARSIP DI ERA DIGITAL: MEMPERTIMBANGKAN KEMBALI SUDUT PANDANG PENGGUNA
}

\author{
Widiatmoko Adi Putranto \\ Program Studi Kearsipan, Sekolah Vokasi, Universitas Gadjah Mada \\ widiatmokoputranto@ugm.ac.id
}

\begin{abstract}
The quick and significant development of information technology in the digital era essentially affects records and archives management. This paper aims to discuss how archives should be aware and understand the social dimension in the challenges and possibilities of managing records and archives in the digital era, including the dynamic of perspectives and behaviours of both internal and external users. In response to the development of information technology, archives put emphasizes mostly in the technical dimension of infrastructure availability and the standard or policy compliance. However, people factor often plays significant role in the transition of management model or system. The best implementation of a standard needs a more holistic approach by considering the users point of view as well as collaboration with various stakeholders in explaining the benefits and functions of the new management system. By putting emphasizes on people factor when conducting training and developing policy, users' resistance can be minimized while users' enthusiasm can be achieved to accelerate the positive result in the adaptation of the new system and trends.
\end{abstract}

Keywords: records and archives management, electronic documents and records management system, digital era

\begin{abstract}
Intisari
Perkembangan teknologi informasi di era digital yang cepat dan signifikan mempengaruhi secara esensial pengelolaan arsip. Tulisan ini bertujuan untuk mendiskusikan bagaimana institusi kearsipan harus menyadari dan memahami dimensi sosial di dalam berbagai tantangan dan kemungkinan yang ada dalam pengelolaan arsip di era digital, termasuk dinamika sudut pandang dan perilaku dari pengguna internal maupun eksternal. Sebagai respon dari perkembangan teknologi informasi, kebanyakan institusi kearsipan memberikan penekanan pada dimensi teknis seperti ketersediaan infrastruktur ataupun memenuhi standar dan kebijakan. Padahal, faktor manusia kerap memainkan peran penting dalam transisi model atau sistem pengelolaan. Implementasi terbaik dari suatu standar membutuhkan pendekatan yang lebih holistik dengan mempertimbangkan sudut pandang pengguna dan juga kolaborasi dengan berbagai pihak terkait dalam menjelaskan manfaat dan fungsi dari sistem pengelolaan yang baru. Dengan menaruh penekanan pada faktor manusia pada saat melakukan pelatihan ataupun merumuskan kebijakan, resistensi pengguna dapat diminimalisir dan pada saat bersamaan antusiasme pengguna dapat dicapai untuk mempercepat hasil positif dari adaptasi pada sistem dan tren terbaru.
\end{abstract}

Kata kunci: pengelolaan arsip, sistem pengelolaan dokumen dan arsip elektronik, era digital 


\section{PENDAHULUAN}

Perkembangan teknologi informasi dengan kecepatannya di era digital dalam dua dekade terakhir telah membawa dampak yang esensial dalam bidang kearsipan. Pengelolaan arsip berbasis kertas yang sebelumnya menjadi konsentrasi dengan segera digantikan oleh format elektronik yang membludak secara kuantitas dan penggunaan. Di era digital, pengelolaan arsip elektronik menjadi tren sekaligus fokus pengembangan pengelolaan dalam banyak institusi. Sejumlah riset telah banyak dihelat untuk mendiskusikan kompleksitas peningkatan kualitas teknis secara konkrit, tantangan, resiko maupun peluang secara umum dalam pengelolaan arsip elektronik agar mampu memberikan kontribusi yang lebih konstruktif bagi pengguna. Seiring dengan proses modernisasi, arsip elektronik dianggap lebih sesuai dengan kebutuhan zaman yang menuntut kecepatan berbagi, kemudahan akses dan fleksibilitas dalam berjejaring. Oleh karenanya, kefasihan institusi dalam beradaptasi untuk mengelola arsip elektronik menjadi penting untuk menjaga keberlangsungan bisnis dan memenuhi kebutuhan informasi.

Kehadiran arsip dalam format elektronik menawarkan sejumlah kemudahan dan berbagai peluang yang sebelumnya tidak dimiliki arsip dalam format fisik dalam pengelolaannya. Sebagai contoh, arsip elektronik memerlukan usaha yang lebih sederhana untuk digandakan atau justru dapat dibagi dengan mudah sehingga dapat meminimalisir duplikasi. Arsip elektronik juga memberikan perubahan yang signifikan dalam kemudahan dan kecepatan untuk melakukan proses pengiriman dan berbagi dibandingkan dengan arsip berbentuk fisik. Selain itu, arsip elektronik juga memberikan peluang bagi institusi untuk menghemat ruangan penyimpanan secara fisik sekaligus membuka peluang akses yang lebih ringkas bagi pengguna. Namun, di sisi lain arsip elektronik juga memerlukan tingkat pengelolaan yang memiliki kompleksitas berbeda dibandingkan pengelolaan arsip fisik. Bagi institusi yang tengah melakukan transformasi pengelolaan dari paperbased menuju paperless maupun digital, tentunya hal ini menimbulkan bermacam tantangan tersendiri.

Pertama, arsip elektronik dengan bentuknya yang tidak memiliki wujud fisik bisa menimbulkan perdebatan terkait aspek legalitasnya. Misalnya, beberapa institusi masih belum dapat sepakat bahwa surat elektronik memiliki kedudukan yang sama dengan surat fisik. Lebih lanjut, institusi-insitusi lain juga masih mempertimbangkan stempel ataupun tandatangan basah sebagai parameter otentisitas. Kedua, kemunculan arsip elektronik merupakan salah satu dampak dari perkembangan teknologi informasi. Institusi-institusi yang sebelumnya mengelola arsip dan dokumen dalam bentuk kertas tidak dapat menghindar pada keharusan untuk berbenah secara teknis maupun kebijakan yang mengaturnya. Transformasi ini biasanya dimulai dengan formulasi kebijakan dan pergantian infrastruktur. Arsip elektronik hanya dapat diakses melalui mesin pembaca seperti komputer dan pada perkembangannya, membutuhkan dukungan jaringan internet untuk berbagi. Berbicara dalam segi perlindungan dan keamanan, aspek elektronik juga rentan terkena virus dan formatnya pun lebih cepat kedaluarsa dan tak terbaca. Juga, meskipun mampu menghemat ruang, kemudahannya mencipta dan berbagi menimbulkan banjir dalam kuantitas. Faktanya, salah satu permasalahan yang umum ditemui adalah bagaimana institusi kerap kali memandang perubahan pengelolaan dari paper-based ke digital sebagai faktor teknis semata. Kebijakan pembelian infrastruktur ataupun penentuan sistem 
aplikasi yang diyakini mampu meningkatkan kualitas fasilitas sering lalai untuk dikompromikan dengan pengelola dan pengguna. Akibatnya, alihalih mampu memaksimalkan potensi peningkatan fasilitas, perubahan pengelolaan arsip dan dokumen berbasis elektronik justru kerap menimbulkan ketakutan pada kegagapan teknologi, kecemasan akan kompleksitas aplikasi, atau bahkan penolakan atas prosedur yang baru.

Perubahan pengelolaan arsip di era digital tidak seharusnya dipandang melalui satu sudut pandang tunggal yang dimiliki institusi saja. Tulisan ini akan mencoba untuk mendiskusikan bagaimana pengelolaan arsip di era digital dapat mempertimbangkan kembali posisi dimensi sosial, termasuk di dalamnya sudut pandang pengelola sebagai pengguna internal maupun masyarakat umum sebagai pengguna eksternal. Institusi tidak semestinya abai terhadap perspektif maupun perilaku pengelola dan pengguna. Sehingga, pengelolaan arsip elektronik sudah semestinya memberikan kontribusi yang lebih konstruktif dengan membuat pengelola dan pengguna mampu mengerti keuntungan yang ditawarkan, kemudahan yang didapat ataupun visi institusi di masa depan dan bukan rasa cemas akan kompleksitas pengelolaan dan akses.

\section{TINJAUAN PUSTAKA}

\section{Pengelolaan arsip di era digital}

Di era perkembangan teknologi informasi yang begitu masif dan cepat, akses pencarian atas informasi juga mendapatkan dampak dan tuntutan yang sama. Internet membawa dampak yang esensial dalam memunculkan jaringan informasi yang luas dan membuat informasi mampu diakses sedemikian cepat. Harries dalam Managing records, making knowledge and good governance mengatakan bahwa perubahan signifikan di era digital membuat banyak orang menginginkan akses informasi instan sekaligus berjejaring dan sebaliknya, tidak lagi mesti melewati struktur hierarkis yang terpusat (Harries, 2009, p.20). Orang mengharapkan mereka mampu mendapatkan informasi tanpa harus menunggu lama ataupun melalui prosedur yang berbelit-belit dan tidak hemat waktu, biaya dan energi. Artinya, hal ini membuat mereka yang berada pada posisi pengelola informasi harus mau dan mampu menyesuaikan tuntutan para pengguna yang didorong oleh dampak situasi dan kondisi lingkungan tersebut. Institusi, tidak terkecuali mereka yang mengelola kearsipan, membutuhkan suatu sistem yang terintegrasi dan mampu secara maksimal berfungsi memenuhi tuntutan tersebut (Reed, 2010, p. 124).

Dalam prosesnya, sebagai dampak dari tuntutan dan keadaan lingkungan yang berubah maka institusi-institusi pengelola informasi berbenah dan melakukan berbagai perubahan pengelolaan informasinya, termasuk pengelolaan arsip. Perubahan ini membangun keahlian dan pengetahuan baru sebagai dampak atas apa yang disebut Gregory sebagai tantangan intelektual masif sebagaimana orangorang akan dituntut memahami cara perangkat lunak bekerja, mampu menjelaskannya kepada orang lain dan berpikir serta bertindak secara berbeda (Gregory, 2005, p. 85). Perubahan ini biasanya direspon institutsi dengan memulai merumuskan kebijakan dan aturan baru, sekaligus melakukan usaha peningkatan terhadap ketersediaan infrastruktur yang mampu menyesuaikan tuntutan dan kebutuhan. Akan tetapi, pada kenyataannya McDonald, sebagaimana dikutip di Wilkins, Swatman \& Holt dalam Achieved and tangible benefits: lessons learned from a landmark EDRMS implementation beranggapan bahwa kemajuan infrastruktur pengelolaan belum berbanding lurus 
dengan kualitas implementasi dari kemajuan itu sendiri (Wilkins, L., Swatman, P. M. C., \& Holt, D., 2009, p.38). Infrastruktur berkualitas bisa jadi telah tersedia, tetapi perumusan kebijakan atas pengelolaan infrastruktur tersebut masih belum dapat memberikan kontribusi maksimal yang nyata kepada penggunanya.

Seringkali, perubahan dilakukan dengan hanya mempertimbangkan satu sudut pandang. Perubahan pengelolaan arsip atas dampak kemajuan teknologi informasi tersebut kerap kali dilakukan dengan fokus memenuhi tuntutan pada kebijakan dan peraturan tertentu semata (Sheperd, 2006, p. 8). Permasalahan yang bisa jadi muncul adalah apakah kepatuhan pada peraturan dan kebijakan tersebut mampu membawa dampak atas perubahan yang diharapkan. Sheperd, Stevenson dan Flinn dalam Records management in English local government: the effect of freedom of information menyatakan bahwa alih-alih mempertimbangkan bagaimana implementasi terbaik pada situasi dan kondisi lingkungan nyata yang ada, kebijakan seringkali menekankan pada memenuhi tuntutan teoritis (Shepherd, E., Stevenson, A., \& Flinn, A., 2011, p. 124). Padahal, McLeod dalam On being part of the solution, not the problem: Taking a proportionate approach to managing records menggarisbawahi bahwa daripada menargetkan kesempurnaan, kemampuan mencari proporsi kebutuhan yang diperlukan sesuai tujuan institusi sehingga progres yang positif dari suatu perubahan dapat dicapai dengan memakai pendekatan yang cocok (McLeod, 2012, p.94). Tanpa adanya dampak signifikan yang ditimbulkan dari implementasi system elektronik, pengguna dan pengelola itu sendiri tentu tidak menyadari adanya perubahan yang diharapkan mampu memenuhi tuntutan dan kebutuhan mereka.
Perubahan pengelolaan arsip di era digital sudah semestinya fokus pada implementasi konkrit yang membawa perubahan dan mampu dirasakan oleh para pengelola maupun penggunanya. Arsiparis maupun pengelola informasi secara umum seharusnya memahami perubahan yang terjadi di sekeliling mereka dan juga jenis pendekatan yang diperlukan untuk menyesuaikan tuntutan atas perubahan yang ada (McLeod, 2012, p.193). Tanpa hal tersebut, suatu institusi pengelola informasi tidak lagi dianggap mampu beradaptasi dan relevan dengan tuntutan zaman dan pada akhirnya ditinggalkan oleh para penggunanya. Oleh karenanya, Sheperd menyarankan perlunya sumber daya yang mampu diandalkan serta memiliki komitmen dan visi jangka panjang (Sheperd, 2006, p. 10). Di samping itu, selain mendefinisikan kembali tujuan keberlangsungan bisnis dan sarananya, sejatinya perubahan pengelolaan arsip dari fisik menuju digital dimaksudkan menggantikan struktur birokrasi dan administratif yang kaku dengan kelompok kerja yang lebih fleksibel dalam suatu institusi (Asogwa, 2012, p. 200). Menurut Harries, dengan penggunaan dan kenyamanan internet yang sudah sedemikian melekat dalam kehidupan sehari-hari masyarakat, respon pengelolaan arsip terhadap tren terbaru seharusnya mampu memberikan sumbangsih sosial yang penting, seperti berpartisipasi dalam peningkatan kualitas layanan dan kebijakan publik dengan memanfaatkan teknologi berjejaring (Harries, 2009, p. 18).

\section{Arsip elektronik}

Kemunculan informasi dalam bentuk elektronik ataupun tren digitalisasi merupakan hal yang tidak terhindarkan sebagai bagian dari proses modernisasi di era digital. Harries menyatakan bahwa saat ini pengelolaan informasi elektronik merupakan hal yang esensial bagi keberlangsungan bisnis 
suatu institusi yang disebabkan tuntutan untuk beradaptasi dengan lingkungan maupun memenuhi kepatuhan pada kebijakan (Harries, 2009, p. 18). Kemunculan informasi elektronik memungkinkan penggunaan informasi dalam banyak tujuan yang berbeda yang sebelumnya belum pernah mampu dicapai (Kallberg, 2012). Sehingga, institusi lebih banyak menciptakan maupun saling berbagi informasi, tak terkecuali arsip dalam format elektronik. Selain itu, pengelolaan arsip elektronik membuat insitusi pada saat terjadi bencana dapat memiliki opsi recovery dengan back-up data (Johnston, G. P., \& Bowen, D. V., 2005, p.134). Suatu hal yang tidak dengan mudah mampu dilakukan dalam pengelolaan arsip fisik. Arsip elektronik diadopsi oleh banyak stakeholders di sektor industri terkait dan karenanya dibutuhkan kemampuan untuk mengelolanya dengan tujuan menciptakan sistem administrasi publik yang lebih efektif dan transparan Meskipun demikian, pengelolaan arsip elektronik memiliki sejumlah tantangan yang kerap kali belum mampu diatasi oleh institusi.

Asogwa menyebut sejumlah tantangan yang dihadapi institusi dalam pengelolaan arsip elektronik seperti keamaan dan privasi, resiko kehilangan data, isu otentisitas, sumber daya manusia dan infrastruktur ataupun kebutuhan pengelolaan secara umum (Asogwa, 2012). Secara umum, institusi pengelola informasi tengah melakukan transisi pengelolaan dari paper-based menuju pengelolaan berbasis elektronik. Transisi ini tak terhindarkan dan bisa jadi dikarenakan apa yang dikatakan Wilkins, Swatman dan Holt (2009, p. 40) bila arsip fisik memiliki sejumlah keterbatasan yang menghambat kebutuhan untuk menyesuaikan tuntutan atas kecepatan informasi pada saat ini. Akan tetapi, hal tersebut kerap kali menjadi kompleks dengan banyak aturan dan kebijakan institusi sebelumnya yang bersifat paper- based (Reed, 2010, p. 125) sehingga implementasi secara bertahap dan transisi yang dilakukan institusi mesti menyesuaikan budaya recordkeeping yang ada (Gregory, 2005, p. 80). Lebih lanjut, dinamika sumber daya manusia menjadi salah satu hal yang memiliki dampak pada isu teknis maupun kebijakan. Sebagai contoh, Harries (2009, p. 18) menyebut ketidakmampuan mengoperasikan sistem ataupun kehilangan dokumen elektronik juga masih terus berlangsung. Menurut Reed (2010, p. 125), biaya pembelian software, lisensi ataupun perawatan kerap kali menimbulkan keengganan karena dianggap terlalu mahal. Akibatnya, tantangan teknis tidak hanya muncul dari keterbatasan infrastruktur melainkan resistensi dari sumber daya manusia yang ada. Padahal, arsiparis disebut Kallberg (2012, p. 112) harus memiliki tekad untuk terus belajar tanpa harus menunggu sumber daya yang mencukupi sehingga membuat mereka dapat tetap relevan.

\section{Dimensi sosial dalam pengelolaan arsip}

Ismail dan Jamaludin (2009, p. 140) menyatakan bahwa bukan hanya infrastruktur semata yang membutuhkan fokus dalam pengembangan pengelolaan arsip elektronik di era digital, melainkan juga faktor manusia. Institusi mesti memahami bahwa pendekatan yang menyeluruh terhadap berbagai elemen amat dibutuhkan di dalam pengelolaan arsip di era digital. Hal ini ditegaskan oleh McLeod, Childs dan Hardiman (2011) yang menemukan bahwa faktor manusia dan hal-hal yang menyertainya saling berkelindan erat dengan faktor proses dan teknologi serta berperan kuat dalam mempercepat transisi yang berdampak positif. Manusia tidak hanya bisa diartikan sebagai pengguna dalam artian masyarakat umum semata, melainkan justru juga termasuk staff pengelola yang 
menjadi bagian dan mengoperasikan pengelolaan itu sendiri. Maka, people issues merupakan hal utama, fundamental dan menantang (McLeod, 2012, p. 189) yang dipercaya Harries (2009, p. 20) tidak boleh diabaikan oleh institusi dalam pengelolaan arsip elektronik di era digital apabila prinsip utama arsip adalah salah satunya untuk meningkatkan akuntabilitas dan tata kelola pemerintahan yang baik.

Sebelum fokus kepada masyarakat atau siapapun pengguna di luar institusi, ada baiknya pengelolaan arsip di era digital yang fokus pada perubahan teknologi dan format elektronik ini mencoba untuk memahami pengguna internal yang tak lain adalah staff pengelola sendiri. Sebab, Johsnton \& Bowen (2005, p. 136) berpendapat bahwa staff kerap kali memposisikan pengelolaan arsip dan dokumen elektronik kerap kali sebagai ancaman karena dianggap jauh lebih kompleks dan bahkan tidak memberikan manfaat (Johnston \& Bowen 2005, p. 136). Hal ini didukung oleh Reed (2010, p. 125) yang berpendapat bahwa ada kendala dalam memberikan penjelasan akan manfaat konkrit yang didapat dengan mudah dan bahwa di antara komunitas yang saling berinteraksi, kebijakan dan nilai kerap kali mengalami dinamika penafsiran (Harries, 2009, p. 23). Maka, tidak jarang ditemui keengganan staff untuk menerima sekaligus beradaptasi terhadap perubahan model pengelolaan. Sebagai contoh, banyak pustakawan dan arsiparis senior di Afrika yang secara psikologi memiliki fobia terhadap perkembangan teknologi karena mereka merasa harus belajar hal baru kembali bersama mereka yang lebih muda dan sebagai akibatnya, tidak lagi merasa menjadi expert dan terancam (Asogwa, 2012, p. 202). Padahal, resistensi staff disebut Wilkins, Swatman dan Holt (2009, p. 43) sebagai salah satu penyebab kegagalan implementasi pengelolaan arsip elektronik. Maka, kegagalan melakukan analisa pada perilaku pengguna internal dapat berakibat fatal. Sehingga, dibutuhkan kemampuan dalam mengelola resistensi ini agar transisi pengelolaan tersebut dapat diimplementasikan secara sukses (Asogwa, 2012, p. 202).

Selain pengguna internal, perspektif dan perilaku publik sebagai pengguna pada umumnya juga perlu mendapatkan pertimbangan untuk memenuhi tuntutan akan keberlangsungan bisnis. Seperti kebanyakan cara berpikir konsumen yang menginginkan untuk mampu melakukan banyak hal dengan lebih sedikit usaha, pengguna arsip pun juga berpandangan demikian (Harries, 2009, p. 18). Maka, menjadi penting bagi arsiparis untuk mampu menganalisa pasar dan menentukan metode terbaik guna terus membuat konsumen tertarik. Standar ideal mesti diterjemahkan pada implementasi terbaik dengan menyesuaikan situasi dan kondisi institusi, maupun kebutuhan pengguna (Sheperd, 2006, p. 10; Asogwa, 2012, p. 201) karena pada hakikatnya, nilai-nilai dan fungsi dasar dari arsip memang diperuntukkan baik bagi pencipta dan pengguna (Dikopoulou \& Mihiotis, 2012, p. 125). Tanpa hal tersebut, pengelolaan arsip di yang berfokus pada transisi perubahan paper-based menuju elektornik tidak akan mampu terimplementasi dengan maksimal. Dimensi sosial, dengan factor people didalamnya merupakan hal yang signifikan karena terkait dengan budaya institusi, cara berpikir dan kepedulian terhadap pengelolaan, preferensi dan kemampuan mengelola arsip (McLeod, 2012, p. 193).

\section{METODE}

Penelitian ini merupakan kajian eksploratif dengan kombinasi metode tinjauan pustaka sekaligus observasipartisipasi secara langsung. Penulis merupakan peneliti dan dosen pada 
program studi Kearsipan sekaligus pernah berpartisipasi secara langsung dalam berbagai pengelolaan arsip pada beberapa institusi pengelola arsip di Indonesia dan Australia. Kombinasi pendekatan yang dilakukan diharapkan mampu memberikan perbandingan antara kajian teoritis dengan praktek di lapangan.

\section{HASIL DAN PEMBAHASAN}

Transisi atas perubahan pengelolaan arsip di era digital sudah semestinya juga mempertimbangkan sudut pandang dan kebutuhan pengguna. Faktanya, Salah satu faktor penyebab kegagalan implementasi pengelolaan arsip elektronik adalah terlalu banyaknya penekanan satu sisi untuk memenuhi standar infrastruktur teknologi informasi dan bukan bagaimana dinamika pengelolaan di institusi dapat secara konkrit berubah (Harries, 2009, p. 18). Pengelolaan arsip di era digital dinilai hanya berdasarkan indikator ketersediaan fasilitas. Padahal menurut Gregory (2005), dibutuhkan kemampuan yang sama untuk memahami perbedaan antara keinginan dan kebutuhan serta budaya dalam suatu institusi acap kali turut memegang perananan dalam proses perubahan tersebut. Elemen-elemen ini tidak ditentukan justru oleh ketersediaan infrastruktur, melainkan sumber daya manusia yang mengelola dan menggunakannya. Teknologi hanya memiliki presentase 20\% karena $80 \%$ perubahan budaya kerja ditentukan oleh kemampuan mengelola isu kultural (McLeod, 2012, p. 193). Oleh karenanya, menjadi signifikan bagi institusi untuk memahami mengapa mereka mesti melakukan hal tersebut dan bagaimana mereka dapat mengakomodasi dinamika perilaku manusia yang terkait.

Institusi mesti menyadari bahwa keberhasilan pengelolaan arsip tidak hanya bergantung dari segi teknis yang memadai, melainkan pendekatan yang lebih holistik dalam mengelola perubahan. Di era digital yang serba terhubung dan berjejaring, Ismail dan Jamaludin (2009, p. 144) berpendapat bahwa dalam mengelola perubahan atas ketersediaan infrastruktur yang baru juga diperlukan transisi cara berpikir untuk memahami pengelolaan arsip yang sistematis dan terintegrasi. Dapat diperdebatkan bila menawarkan cara berpikir baru membutuhkan proses yang membutuhkan usaha jauh lebih besar dibandingkan melakukan akusisi fasilitas. Faktanya, menerapkan pengelolaan arsip elektronik memang disebut membutuhkan proses yang panjang dan kompleks (Gregory, 2005). Sebagai contoh, dalam satu kasus kesalahan pemahaman pada perubahan sistem justru menimbulkan satu situasi dimana arsip yang sudah terlahir digital justru dicetak untuk kemudian dikelola dengan perlakuan sebelumnya sebagaimana arsip kertas (Sheperd, 2006, p. 9). Hal tersebut nampaknya sepele, namun bisa jadi merupakan kasus yang tidak jarang terjadi di banyak institusi karena secara fundamental terjadi kekeliruan cara berpikir dan mengelola perubahan. Informasi yang terkandung dalam kebijakan maupun panduan teknis faktanya masih kerap kali menjadi multitafsir dan menimbulkan konflik di antara semua pihak yang berkepentingan (Harries, 2009, p. 19). Tanpa kemampuan memahami sudut pandang pengguna dan mengelola kebutuhan mereka, perubahan pengelolaan arsip akan kesulitan memastikan transisi dan implementasi sistem yang baru dapat berjalan dengan maksimal. McLeod (2012, p. 193) bahkan percaya bahwa dibandingkan teknologi itu sendiri, berbagai isu sumber daya manusia sebagai pengguna teknologi yang diimplementasikan jauh lebih penting. Implementasi yang sesuai tidak mampu serta merta didapatkan hanya dalam sekejap dan membutuhkan usaha untuk meningkatkan kualitas maupun 
menyelesaikan berbagai kendala yang mungkin ada dari berbagai sisi.

Pengelola dan pengguna bisa jadi akan mempertanyakan mengapa perubahan perlu dilakukan dan bukan tidak mungkin resistensi internal di dalam institusi itu sendiri akan terjadi. Menurut Ryan (2005), kehadiran infrastruktur tidak serta merta membuat pengelola dan pengguna yang terdampak mampu mengerti apa fungsi dan manfaatnya dalam praktek atau bisnis yang dikelola institusi. Faktanya, bukan data, sistem atau infrastruktur yang diberikan yang terpenting melainkan memahami cara mengelola hal-hal tersebut (Yahaya, sebagaimana dikutip di Asogwa, 2012, p. 200). Maka, menjadi esensial bagaimana pemahaman akan perubahan disampaikan dan diterjemahkan dalam suatu penjelasan yang mampu dimengerti semua pihak. Membuat people merasa diikutsertakan dalam setiap proses perubahan dalam pengelolaan arsip yang lebih baik menjadi penting (McLeod, Childs \& Hardiman, 2011) karena penerimaan dari mereka, selain memberikan pengertian apa manfaat yang didapatkan, akan mendorong kesadaran dan kemauan untuk menggunakan sistem tata kelola yang baru (Johnston \& Bowen, 2005, p. 136). Menyampaikan pemahaman yang memadai dan mampu diterima oleh semua pihak yang berkepentingan menjadi salah satu tantangan yang dihadapi institusi.

Sebaliknya, proses perubahan akan terkendala apabila pemahaman tidak secara merata dimiliki oleh semua pihak. Studi yang dilakukan Hagmann (2013) mengingatkan bahwa inisiatif kebijakan yang hanya mempertimbangkan satu sudut pandang dapat menimbulkan bias. Oleh karenanya, penting bagi suatu institusi untuk melakukan pendekatan secara menyeluruh baik dari sisi pencipta, pengelola maupun pengguna. Sehingga, apa yang dikatakan oleh Beach dan Oates (2014, p. 43) bahwa pemahaman yang sama di antara semua pihak terkait dan berkepentingan dengan pengelolaan maupun penggunaan arsip sebagai hal yang wajib dapat tercapai. Berbicara dalam konteks psikologis, perubahan juga bukan hal yang disukai oleh kebanyakan orang. Secara umum, orang cenderung memilih untuk tidak berubah ketika mereka memiliki pilihan tersebut sehingga dibutuhkan kombinasi antara persuasi dan paksaan (Gregory, 2005 , p. 84) atau bahkan ganti rugi dan hukuman guna menumbukan kemauan yang mendasar untuk melakukan perubahan pengelolaan dengan lebih baik (McLeod, Childs \& Hardiman, 2011). Mengelola perubahan guna meningkatkan pengelolaan arsip yang sesuai dengan tuntutan zaman membutuhkan kemampuan untuk melihat dinamika perilaku manusia.

Menyelenggarakan pelatihan dan pemanduan menjadi salah satu cara untuk mengakomodasi kebutuhan pengguna internal dan eksternal dalam mengelola perubahan. Memungkinkan proses belajar, salah satunya lewat pelatihan, disebut Harries (2009, p. 23) mampu meningkatkan kemampuan di antara semua partisipan. Akan tetapi, proses ini bisa jadi akan terkendala banyak hambatan seperti jumlah mentor yang dibutuhkan yang cukup banyak, tempat serta situasi dan kondisi yang mencukupi sehingga membutuhkan waktu, energi dan biaya yang bisa jadi tidak mampu dijangkau oleh institusi. Faktanya, pelatihan yang sedemikian intensif juga tidak menjamin apabila sistem yang diimplementasikan kurang user-friendly, tidak mudah dipahami manfaatnya atau justru menimbulkan konflik dengan kebijakan atau proses pengelolaan sebelumnya yang sudah ada. Sebelum mengeset suatu sistem dalam pengelolaan arsip elektronik di suatu institusi, diperlukan pengenalan dan penjelasan prinsip-prinsip dasar pengelolaan arsip dan dokumen 
elektronik serta kemauan institusi melakukan perubahan (Maguire, 2005) serta apa fungsi dan manfaat yang didapat bagi mereka yang terdampak (McLeod, 2012, p. 193) secara sederhana dan mudah dipahami maupun diakui (Harries, 2009, p. 18) oleh staff dengan latar belakang teknologi informasi yang berbeda-beda (Johnston \& Bowen, 2005, p. 136). Konteks non-teknis inilah yang menjadi salah satu segi fundamental yang harus disampaikan dalam suatu pelatihan.

Perubahan pengelolaan arsip di era digital tidak seharusnya dimaknai sebagai perubahan fisik pengelolaan arsip dari paper-based menjadi elektronik. Selain kesiapan mengakomodasi pertanyaanpertanyaan tak terduga yang menjadi kebutuhan pengguna (Gregory, 2005, p. 84), Johsnton dan Bowen (2005, p. 136) menggarisbawahi bahwa pelatihan memegang unsur penting dalam menjelaskan bukan hanya bagaimana suatu perangkat lunak bekerja, namun juga penjelasan mendasar mengapa pengelolaan arsip berbasis elektronik diperlukan, bagaimana dampaknya pada pengguna sekaligus memberikan antisipasi untuk meredakan kecemasan akan perubahan. Standar dalam pelatihan pun juga seharusnya lebih cair dan tidak bergantung pada satu formula yang kaku. Sebaliknya, pelatihan mesti diberikan menyesuaikan dengan kebutuhan institusi dan kapasitas sumber daya manusianya (Gregory, 2005, p. 80).

Pada akhirnya, perubahan membutuhkan dukungan yang terintegrasi dari berbagai aspek dan manajemen dalam institusi. Diperlukan dukungan dari manajemen senior dan adanya tim khusus yang mengelola perubahan untuk melewati masa transisi dengan lebih mudah (Gregory, 2005). Institusi juga mesti mempertimbangkan kebijakan baru dalam mengatur perubahan sekaligus efeknya bagi penerapan sistem pengelolaan yang baru. Akan tetapi, Willis (2005) menyebut bahwa kebijakan tidak berguna tanpa implementasi yang efektif dan sistem yang diterapkan harus realistis, sesuai dengan kebutuhan organisasi, dan terintegrasi. Integrasi menjadi elemen penting di era digital yang membutuhkan akses berbagi yang instan dan akurat. Integrasi menjadi kebuthan sekaligus tantangan karena acapkali sukar untuk diterapkan secara menyeluruh. Selain itu, integrasi juga mesti tidak hanya dimaknai dalam konteks sistem melainkan juga seberapa sinkron kebijakan yang dicetuskan (Sheperd, Stevenson \& Flinn, 2011). Harries (2009, p. 22) juga menunjuk pentingnya integrasi dalam jaringan pengelolaan arsip elektronik di antara semua stakeholders terkait. Integrasi ini juga mendapat tantangan besar mengingat banyaknya sektor publik di Indonesia yang bahkan masih belum memiliki pengelolaan arsip berbasis elektronik hingga saat ini.

Pada akhirnya, kemauan untuk terus belajar dan berkolaborasi juga turut memegang peran serta. Dengan semakin eratnya kebutuhan keahlian untuk memahami perkembangan teknologi informasi, Asogwa (2012) menekankan pentingnya kerjasama dan keterlibatan dengan professional lain yang juga memiliki perhatian di bidang teknologi informasi. Mengantisipasi perubahan pengelolaan arsip di era digital membutuhkan kerjasama dengan berbagai pihak dan sudah semestinya dilakukan dengan pendekatan yang mengakomodasi berbagai ide, kebutuhan dan sudut pandang yang terkait.

\section{KESIMPULAN}

Perubahan pengelolaan arsip di era digital perlu dilihat tidak hanya dalam konteks teknis saja. Sebaliknya, pengelolaan arsip di era digital sudah semestinya mempertimbangkan sudut pandang pengguna dan dinamika perilaku dan kebutuhan semua yang terkait. Pemahaman manfaat dan fungsi 
secara nyata mesti diterjemahkan secara sederhana sehingga mudah dimengerti oleh pengguna. Namun, institusi juga mesti memperhatikan kebutuhan dan perubahan apa yang diperlukan secara spesifik bagi mereka sendiri. Kerjasama dan kolaborasi mampu menunjang keberhasilan untuk terus berproses dalam mengantisipasi perubahan pengelolaan. Selain memegang peranan penting dalam dampak perubahan dan implementasi dari cara pengelolaan yang baru, mengakomodasi perspektif dan dinamika kebutuhan pengguna menjadi hal wajib dalam menjaga relevansi pengelolaan arsip yang sesuai dengan tuntutan zaman, keberlangsungan bisnis, sekaligus mampu memberikan kontribusi berkelanjutan yang konstruktif.

\section{DAFTAR PUSTAKA}

Asogwa, B. E. (2012). "The challenge of managing electronic records in developing countries: Implications for records managers in sub Saharan Africa" in Records Management Journal, 22(3), 198-

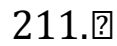

Beach, J. \& Oates, J. (2014). "Information governance and record keeping in community practice" in Community practitioner: the journal of the Community Practitioners' \& Health Visitors' Association, 87(2), 43.

Dikopoulou, A., \& Mihiotis, A. (2012). "The contribution of records management to good governance" in The TQM Journal, 24(2), 123-141. Gregory, K. (2005). "Implementing an electronic records management system: A public sector case study" in Records Management Journal, 15 (2), 80-85.

Hagmann, J. (2013). "Information governance-beyond the buzz" in Records Management Journal, 23(3), 228-240.

Harries, S. (2009). "Managing records, making knowledge and good governance" in Records Management Journal, 19(1), 16-25.

Ismail, A., \& Jamaludin, A. (2009). "Towards establishing a framework for managing trusted records in the electronic environment" in Records Management Journal, 19(2), 135146.

Johnston, G. P., \& Bowen, D. V. (2005). "The benefits of electronic records management systems: A general review of published and some unpublished cases" in Records Management Journal, 15(3), 131175.

Kallberg, M. (2012). "Archivists 2.0: redefining the archivist's profession in the digital age" in Records Management Journal, 22(2), 98-115.

Maguire, R. (2005). "Lessons learned from implementing an electronic records management system" in Records Management Journal, 15(3), 150-175.

McLeod, J. (2012). “On being part of the solution, not the problem: Taking a proportionate approach to managing records" in Records Management Journal, 22(3), 186197.

McLeod, J., Childs, S., \& Hardiman, R. (2011). "Accelerating positive change in electronic records management-Headline findings from a major research project" in Archives \& Manuscripts, 39(2), 6694.

Mnjama, N., \& Wamukoya, J. (2007). “Egovernment and records management: an assessment tool for e-records readiness in government" in The Electronic Library, 25(3), 274-284.

Reed, B. (2010). "Service-oriented architectures and recordkeeping" in Records Management Journal, 20(1), 124-137. ?? 
Ryan, D. (2005). "The future of managing electronic records" in Records Management Journal, 15(3), 128-176.

Sheperd, E. (2006). "Why are records in the public sector organizational assets?" in Records Management Journal, 16(1), 6-12.

Shepherd, E., Stevenson, A., \& Flinn, A. (2011). "Records management in English local government: the effect of freedom of information" in Records Management Journal, 21(2), 122-134.

Svärd, P. (2014). "The impact of information culture on information/ records management: A case study of a municipality in Belgium" in Records Management Journal, 24(1), 5-21.

Wilkins, L., Swatman, P. M. C., \& Holt, D. (2009). "Achieved and tangible benefits: lessons learned from a landmark EDRMS implementation" in Records Management Journal, 19 (1), 37-53.

Willis, A. (2005). "Corporate governance and management of information and records" in Records Management Journal, 15(2), 86-97. 